\title{
Optimization of the Development of the Record Center Faculty of Social and Political Sciences University of Lampung
}

\author{
Purwanto Putra \\ Faculty Of Social Science And Political Science \\ Lampung University \\ Lampung, Indonesia \\ purwanto.putra@fisip.unila.ac.id
}

\author{
Roby Rakhmadi \\ Faculty Of Social Science And Political Science \\ Lampung University \\ Lampung, Indonesia \\ roby.rakhmadi007@fisip.unila.ac.id
}

\begin{abstract}
The issue of the record center has become a national public discussion. The debate about the urgency of the physical construction of the archive building is considered ineffective because it will waste the budget as opposed to the electronic or digital storage model in i-cloud storage media (cloud storage). Universities are institutions that should carry out the Tridharma of Higher Education, namely education, research, and community service (Indonesia. Ministry of Education and Culture, 2012). The three business activities will be closely related to the archive. Information management in higher education will be largely determined by the management of its archives, both dynamic, in-active, and static archives. This is important when looking at what is the scope and function of archives in higher education institutions. Archives are collective memory, both individuals and institutions (Grau, 2017). Archives can serve as evidence and accountability for various activities (Randall C. Jimerson, 2007). In addition, the archive is also a source of information that is needed in personal or institutional life (Paul H. Mc Carthy, 1988). This research, which was held at FISIP Unila, aims to find out which archive center is the most appropriate choice for FISIP UNILA, which is currently in the process of setting up an archive center. This study uses a descriptive approach with qualitative methods. The method of collecting data is through observation, interviews at FISIP UNILA, as well as various literature studies. The main problem that is currently being faced because it does not have a record center (archive center) is the occurrence of archive life cycle gaps and also hinders various archiving work activities at the University of Lampung. Through this research, it is hoped that the following specific objectives will be achieved, namely: (1) Accelerating the process of developing a record center at
\end{abstract}

FISIP UNILA. (2) Help run the archive cycle in a structured and integrated manner, through the management of dynamic archives, in-active archives, and static archives in a structured manner in terms of their storage to conform to archival standards.

Keywords- Pusat Arsip, Records Center, Unila Fisip.

\section{INTRODUCTION}

The issue of the archive center (record center) surfaced and became a hot topic of discussion in the public sphere nationally. From the end of 2019 until the beginning of 2020., the Minister of state-owned enterprise (BUMN) canceled the plan to build a stateowned enterprise (BUMN) archive building [6]. He considered that building construction has the potential to waste the budget due to changes in information storage media so that now archives can be stored electronically or digitally in i-cloud storage media (cloud storage) [10].

Is it that simple the issue of archives and archive centers? This caught the attention of some people and archival observers. Archives will naturally grow and develop, on the other hand, information needs in archives require fast and appropriate services [4]. Therefore, professional archive management based on standardized standards is a must. Additionally, archives have various values; such as historical value, economic value, evidence value, so that its preservation and safety must be a priority in its management [3].

Universities are institutions that should carry out the Tridharma of Higher Education, namely education, research, and community service [11]. The three business activities will be closely related to the archive. Archives are by-products of an activity or business transaction so that at universities, three types 
of archives will be created - archives are the documentary by-product of human activity retained for their long-term value. They are contemporary records created by individuals and organizations [9]. Next is to manage in-active archives in the form of a record center (archive center) which is within the scope of the faculty and UPT and the third is an archive unit or archive depot at the level of UPT which specifically handles static archives for the university scope. The current condition at the University of Lampung, each faculty does not yet have a record center (archive center), even if there is it is still limited as an archive warehouse because the documents have not been managed systematically and there are no archivist resources that specifically handle this. The impact is not once or twice so many obstacles in the business activities of the organization when it requires the support of these inactive records.

In-active archives are archives that are not used in the daily activities of the organization, but at some point, they will be needed, for example during study program accreditation, during monev, or when opening a new study program. The archive warehouse will be very different from the archive center (record center) because each archive center will have a record management system consisting of SOP (Standard Operational Procedure), JRA (Archive Retention Schedule), PKS (Subject Classification Guidelines) DPA (Archive Description List), and DSS (Achievement Facilities and Infrastructure) [18] Just as at the University of Lampung itself, the Archives Retention Schedule (JRA) was determined through the Decree of the Chancellor of the University of Lampung Number 4 of 2016 which was set on April 20,2016 , the purpose of which was not only to support archive management at the University of Lampung but also to fulfill the mandate of the law [1].

In addition, the challenge is getting bigger in the era of ICT (Information and Communication Technology) that university archives are not only in conventional form (paper) but also in a digital form known as electronic archives (e-archive) [5]. In terms of managing electronic records, more attention must be paid because they require special guidelines and human resources who have special skills and competencies in archive management.

The main problem currently facing the development of university archives, especially the University of Lampung which does not yet have a record center (archive center) in each faculty and UPT, is that there is a gap in the archive life cycle, which cannot run and hampers all archival work activities in the scope of the archives. Lampung University. The records or archives created/received by each work unit (study program and department) are sufficiently organized and documented by the staff.

The biggest problem is in the next stage or cycle when the archive is no longer used for daily activities and must be retained as an inactive archive, in which there should be an orderly archive transfer process to the archive center or record center in the faculty. But due to the absence of a record center, the process cannot run. The impact is twofold, first, in-active archives accumulate in the work unit (central file) or in-active archives are sent to archive warehouses without a systematic data collection and documentation process. Until then it becomes piles of documents and at the same time, the archive is lost in the pile because it is very difficult to retrieve it when it is needed.

Another problem with the absence of a representative record center (archive center) is the delay in the acquisition of static archives by the UPT Archives, University of Lampung. In theory and generally accepted, of all archives created/received, only 5 percent of active archives turned into static archives [8]. The rest will be in-active records which after entering the retention period and going through the assessment stage can be destroyed because they have no use value, both informational use-value and evidence use-value. We can imagine together the magnitude of the impact that will be caused by the absence of a representative and standardized record center for the development of the University of Lampung institutions at this time and in the future in terms of archive management.

The University of Lampung as a higher education institution has a D3 Library Study Program which has been established in 2001 at the Faculty of Social and Political Sciences, Lampung University, also develops various courses on Archives and has several experts in the field of archiving [15]. Therefore, it is an obligation to share knowledge and skills in the realm of archiving specifically for the Lampung University Institution as its shelter and to the community in general.

Therefore, through this research, we will try to study in-depth the needs and requirements for developing an archive center (record center) at the University of Lampung. For the case study, the research location is the Unila FISIP Record Center Development. FISIP was chosen because currently, archive management activities in the faculty are underway so that this can go hand in hand, and hopefully, they will be able to support each other.

\section{LITERATURE REVIEW}

\section{A. Archive}

Archives according to Law Number 43 of 2009 concerning Archives are recordings of activities or events in various forms and media according to the development of information and communication technology made and accepted by state institutions, local governments, educational institutions, companies, political organizations, community organizations and individuals in the implementation of 
social, national and state life (Law of the Republic of Indonesia Number 43 of 2009 [22].

Along with the organization's business activities, the archives created are increasing all the time. If the archive is not managed properly, the archive will become an unorganized archive and the impact is detrimental to the archive creator [19]. Archives as an authentic and reliable source of information if not stored according to the correct rules will make it difficult to retrieve them. Archives as evidence of liability and legal evidence will be a problem when not managed in good management [2].

In terms of terms, the term archive can be translated into records, records, and scripts. Archives as recorded information regardless of the media or format created, received, and maintained by an agency, institution, organization (hereinafter referred to as agency/institution), or individual following legal obligations or as a result of business transactions or as a result of their activities. Generally, records are prosaic, created to facilitate public and private business. Records are used to justify official actions; to record proceedings; to explain and record official decisions; and to safeguard the rights of citizens, companies, and governments under the law.

\section{B. Archive Center (Records Center)}

In the explanation of article 47 paragraph 1 of Government Regulation Number 28 of 2012 concerning the Implementation of Law Number 43 of 2009 concerning archive [20], it is stated that inactive archive storage is carried out at an inactive archive center or records center as a place for storing inactive archives in buildings designed for archive storage.

The Bekasi Regency Government has required every OPD to have an archive center (records center) as a means of storing inactive archives, as stated in Regional Regulation Number 2 of 2014 concerning the Implementation of Archives article 74 paragraph 4 that "Every OPD, Archives Institution, Village Government and BUMD are required to provide facilities and infrastructure for archive storage space.

The Archive Center or records center is a place and all facilities specifically designed to store inactive archives. The existence of an archive center must go through planning, meaning that an archive center does not just happen because a room is full of piles of archives, then it is called an archive center. The archive center was created because of the needs of the organization, so it needs to be specifically designed to meet certain criteria and can support the achievement of records management goals.

\section{C. Archive Center Building Qualifications}

Archives center buildings or buildings should have special characteristics and reflect that the building directly contains nuances that are close to the archives. Without entering the building, anyone should know that the building is an archive center. However, this situation cannot be realized in Indonesia, because architecturally it is difficult to standardize.

Archive center building materials should not be materials that are easy to attract termites or ants (eg wood). The windows are kept to a minimum, but still must be able to ensure good and smooth air circulation. If necessary, each window is given reinforcement or trellises. Likewise, the facing position of the building, windows, doors must be made in such a way that sunlight, wind, or dust do not directly enter the room and hit the archives.

The archive center building should be made higher because a high room will optimize the use of space. It's better not to be multi-level, but the archive rack is tiered. The archive center building does not need to be designed with full ac. The establishment of a record center as a record storage facility is carried out based on the principles of expediency; security and safety; balance; the compatibility of the building with its environment; and accessibility.

Meanwhile, in general, the activities of establishing a record center as a record storage facility include development planning; implementation of spatial planning, and infrastructure and facilities. In principle, an archive center is managed and handled by archivists or staff who have competence in the field of document and record management obtained through formal education or archival education and training.

The planning for the construction of a record center as a record storage center is carried out by considering the following conditions: location; size; area within the building; structure and construction; and protection, safeguarding, and including control. In addition, it should also be noted that the determination of the location of the record center as a record storage center must take into account the climate, vegetation, geology, and legal aspects of the location and all licensing requirements.

The location as much as possible should be in an area that is far from things that can endanger or interfere with the physical security (information) of each of the records stored. To protect the physical record of giving anti-pest drugs before and after construction or when using the building, it is necessary to do it. What is also important is the availability of a good drainage system. In addition, there must also be available transportation facilities that are easily accessible.

In considering the climatic aspects of the location of the record center as a record storage center, one must also pay attention to the tropical climate of the Indonesian region which has the following characteristics: Equatorial humid zone with high temperatures between $26^{\circ}$ to $27^{\circ} \mathrm{c}$; Humid tropical zone with high temperature and relative humidity all year round; A tropical savanna zone with a prolonged 
dry season and very intense solar radiation. Therefore, determining the location of the record center as a record storage center must be free from vegetation that can contribute to increased humidity, causing the risk of insects and micro-organisms to come that can damage documents and records.

Determination of the location of the record center as a record storage center must consider the following geological aspects: Free from damp areas, swamps, seas, rivers, or flood-prone areas; Free from strong wind or storm areas; Free from dry wind areas and sandy soil; Free from industrial areas that produce dust or other contaminating substances; Free from high voltage power lines, nuclear power plants or buildings containing flammable and explosive materials; Outside terminal areas, airports, stations, ports or areas with high-intensity traffic with the risk of noise and air pollution; Outside the identified seismic activity zone; and the center of commercial and industrial areas.

The legal status of land for the construction of a record center as a record storage center must meet the following requirements: Status of land ownership rights and utilization permits from land rights holders; Building ownership status; Permit to construct a building; Free from disputes and other legal problems.

The size and layout of the record center building as a record storage center are carried out based on: Types of records being managed; The need for work area and administrative functions; The volume of records managed by the record center; Estimated addition of repertoire of records up to 50 (fifty) years into the future.

The space in the record center building as a record storage center includes workspace; Storage space; Public area; Technical installation room. The structure and construction of the record center as a record storage center are designed based on the following considerations: Future expansion plans; Able to bear large loads; Have a stable thermal condition; Accommodating building construction with architectural quality according to standardization.

Protection, security, and control are carried out against various factors of damage to elements that are intentional and unintentional, covering 2 things, namely: natural factors and human factors.

\section{RESEARCH METHOD}

This research uses a qualitative approach. Qualitative research is inductive, and researchers generally explore meaning and insights into specific situations. Given (2008) in [21] said that the qualitative approach consists of philosophical perspectives, assumptions, postulates, and this approach makes the research results open to analysis, criticism, replication, and further adaptation [21]. In this case, the researcher uses qualitative methodology as a research tool to design the study, collect and analyze the data. This approach is used to answer questions and describe the phenomenon of the development of the archive center at FISIP, University of Lampung.

The research was carried out for eight months from the preparation of the proposal in April 2021 until reporting in September 2021. It was carried out in an archive unit (archive room) which would be developed into an archive center or record center at the Faculty of Social and Political Sciences, University of Lampung. The object of research in this research are the leaders of Fisip Unila, who have the authority to make policies regarding the archives center, document managers (archivists) at the record center, Faculty of Political and Social Sciences, University of Lampung. In addition, it will also dig up information from informants from the Unila Archives Unit as partners in this research.

The data collection used in this research is thorough observation, interviews, and document studies. Informants involved in the research will be selected based on the purposive sampling method. Observations were made to observe the behavior of informants in serving, doing their daily work. In the interview process the questions asked were questions about the authority of the Fisip leadership in developing a record center according to the Unila Fisip Strategic Plan, also exploring the work process of document management staff, what roles they played and how these roles were carried out to social changes in the workplace in an organization. universities and the development of information technology.

Meanwhile, in collecting data using document studies, documents will be seen, linked, and interpreted as evidence of the role of archivists and organizational achievement documents. Data collection methods on. In this study, through documentation techniques, as a typical field of information, researchers will collect documentary evidence that can support and strengthen research data.

At the data analysis stage, the researcher analyzes the data that has been collected by understanding the overall research data. Data analysis in question is the process of systematically searching and compiling data obtained from interviews, field notes, and documentation, by organizing data into categories, describing them into units, synthesizing, compiling into patterns, choosing which ones to use. important and what will be studied, and make conclusions so that they are easily understood by themselves and others. As for the data analysis technique that the researcher uses, refers to the interactive data analysis model according to Miles and Huberman, the activities carried out during the period of data collection to reporting include three parts, namely data reduction (data reduction), data display (data presentation), and conclusion drawings. verification (verification) [12]. 


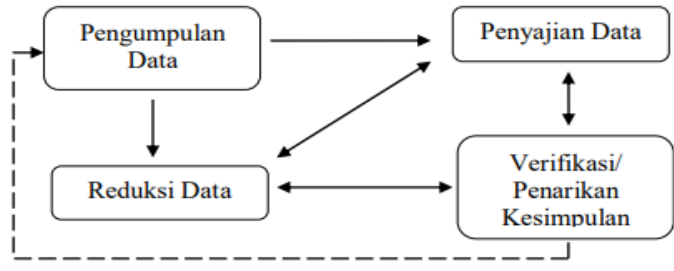

Fig 1. Interactive data analysis model (Miles and Huberman)

\section{RESULTS AND DISCUSSIONS}

\section{A. Understanding of UNILA FISIP Archive Center}

Archives are collective memory, both individuals and institutions [7]. Archives can be a means of evidence and accountability for various activities [16]. Archives are a source of information that is needed in personal or institutional life [13]. In general, archives can be grouped into three types, namely: a) Dynamic Archives, b) Inactive Archives and c) Static Archives [17]. Dynamic Archives are archives that are still used in institutional activities, often also referred to as records. While Static archives are archives that are rarely used in organizational activities.

Records or in Law Number 43 of 2009 concerning archive [22] are stated with archives which are defined as recordings of activities or events in various forms and media according to the development of information and communication technology made and accepted by State institutions, local governments, educational institutions, companies, organizations politics, community organizations and individuals in the implementation of social, national and state life.

From the definition above, it can be observed how vital records or archives are in the organization, it is even explicitly stated that the scope of records also covers various types of organizations, including companies. As a company that continues to grow, FISIP, University of Lampung certainly has an absolute and non-negotiable interest in this record. The existence of these guidelines further strengthens the existence and role of the records created and managed by FISIP, the University of Lampung as assets and evidence. This guide can be used as a reference and direction for managing these records.

A record center is a building or room that is generally designed to be a center for inactive record storage and services. The record center takes care of integrated inactive archive management. The things that generally become the scope of the record center's work include processing, storage, depreciation, maintenance, and reference services. Technically, it is certain that along with the ongoing business activities at FISIP, the University of Lampung, there will also be an increase in the number of records. Handling these records requires systematic and directed management by following established procedures. If records are not managed by following the rules that have been determined, the existence of records will even become difficult (loss, use without responsibility, difficulty in retrieval, damage or loss) and even potentially threaten the business activities of FISIP, the University of Lampung as the creator of the record.

Records as an authentic and reliable source of information must be managed according to the correct rules to further increase the ability and strength of the organization's business, and even become a high-value asset for the organization. For example, when these records are needed as reference material, evidence of liability, and legal evidence, this can be done without significant obstacles. To carry out such good management and management, the organization cannot be separated from projections and planning for the development of a record management system. This can be done through mapping the current condition of records and the record center at FISIP, University of Lampung. Then an important point is to estimate the development of the number (volume) of records, at least in the next 20 years.

The things mentioned above will certainly be greatly influenced by several factors, including the condition of the building, space, and record storage facilities, including the existence of records and vital records which are part of the company's assets. Vital records and records become very valuable because in the absence of loss or damage they cannot be replaced. So that which can certainly disrupt or even paralyze the company's business activities.

Furthermore, it should also be understood that the record center is a vital work unit in carrying out record management responsibilities. The record center as explained by Law Number 43 of 2009 concerning Archives [22] is a work unit for archive creators who have duties and responsibilities in the administration of archives. Again, he emphasized that every company, including FISIP, University of Lampung, should establish a record center with clear responsibilities and authorities and follow a professional record management policy.

In practice, a record center is a place and all facilities specifically designed to store inactive and vital records. Thus, the development of a record center must go through directed and structured planning, meaning that a record center does not just exist, where there is a room full of piles of records and archives, so that it deserves to be called a record center. In principle, the development of a record center must be based on the needs of the organization. So it is necessary to do a special design to meet certain criteria and function requirements in order to support the achievement of record management goals.

It was reaffirmed that in principle the record center has the task of managing inactive records submitted by the work unit, when there are other tasks that are secondary in nature. In more detail, the task is to keep 
records of inactivity from work units that have retention under 10 years. In the following, we try to describe the condition of the existing FISIP record center at the University of Lampung as a first step before preparing the overall record center development guide and technical preparation of inactive record storage rooms and vital records.

Higher education is an institution that strongly emphasizes the principle of best service (service of excellence) to the academic community and stakeholders and organizational culture (good corporate culture) based on documents and archives. Higher education information services are in direct contact with various campus and community life activities ranging from services in the field of education, research, and community service. If universities manage archives well, then optimally information services and business activities will be achieved to support the "tri dharma" of higher education.

So it can be said that the management of information in higher education will be largely determined by the management of its archives, both dynamic, in-active, and static archives. One of the characteristics of archives is that they have a life cycle, starting from active, in-active, and static archives which run in a non-negotiable linear fashion [14]. One cycle does not run it will disrupt the entire activity. Therefore, in the management of university archives, each unit with its scope of work is needed, starting from the central file to managing active archives which are generally located in work units, study programs, or majors.

Based on its location, the archive center or record center of FISP UNILA chose to use the on-site records center model/concept (inside location) this was chosen with consideration of cost, cost savings. Even though FISIP's location is not very wide. However, there is still room or location that can be used as a record center. The space has been used as an archive warehouse and BMN work unit. To accommodate the needs of the rooms or other facilities needed, a large room is also prepared which is adjacent to the archive warehouse.

Another thing to consider because FISIP Unila is new to the concept of an archive center, the development of this archive center is the first to be initiated and most likely also the first in the University of Lampung. In principle, the archive center built at Unila is integrated with the office building (building A 2nd floor) Fisip Unila and is one part of the office building.

Archive centers that are built outside of office buildings (Off-site records centers) have not been an option and may not be selected for some time in the future or become a matter of thought, especially now it is very possible to develop archives electronically.
Instead of adding a physical archive storage location, you have to allocate a place that is outside of the UNILA FISIP.

Broadly speaking, apart from the issue of location availability and economic cost savings. There are several other factors that Fisip Unila also considers in determining and selecting the location of its archive center, namely:

\section{1) Cost Factor}

FISIP Unila considers the cost factor which includes the procurement and maintenance of facilities to be carefully considered when choosing a place to build this archive center. It is also necessary to consider the cost of retrieval and delivery of archives, so the location chosen must be strategic.

\section{2) Access}

FISIP Unila considers this access/road to have a big problem. However, it must still strive that the storage carried out still ensures that the archive can be served quickly and accurately. Therefore, it is necessary to consider completing the delivery facilities and permission to use archives for users who come to the archive center.

\section{3) Transportation}

FISIP Unila considers the transportation of archives and employees who work at the archive center needs to be the basis for consideration so that the process of retrieval and delivery of archives can be carried out easily. Similarly, employees who work in the archive center also go to their assignments and go home easily.

\section{4) Safety and Security}

FISIP Unila considers the safety and security of records as a major concern in records management. Archives must be obtained through the authority of employees, free from theft and disturbances of damage from animals, fire, water, wind, heat, pollution, and others.

\section{B. Recommendation for Storage Room for UNILA FISIP Archive Center}

Records should not be stored in the ceiling or basement area. These areas do not meet the standard requirements for record-keeping unless steps have been taken to minimize any risks.

Steps to be taken to ensure that records are protected. For example, if records are stored in the basement, the space must be watertight and well ventilated, the humidity level should be adjusted and storage shelves should be raised from the floor by a minimum height of $100-150 \mathrm{~mm}$ to prevent waterlogging or flooding.

If the record center is already overcapacity and requires storing records at the same time as or adjacent to the work area, it must be able to minimize the potential for record damage while still paying attention 
to the comfort and health of employees. For example, because records should not be stored under windows or on the edge of a building wall, consider that these areas are generally hotter. Enclosed spaces are better for record preservation but tend to hurt employees. So the best solution is to choose a storage facility in the form of a shelf with a cover (mobile shelving).

TABLE I.

THE BEST SOLUTION IS TO CHOOSE A STORAGE FACILITY

\begin{tabular}{|c|c|c|}
\hline No & Areas of Attention & $\begin{array}{c}\text { How to Minimize Risk on Records } \\
\end{array}$ \\
\hline a. & Storage space and equipment & $\begin{array}{l}\text { Storage space and equipment must be locked and access supervised (level } \\
\text { of access) by those who have the authority and responsibility (if records are } \\
\text { in conjunction with workspaces then shelves must be locked, the choice can } \\
\text { be in a vault or mobile shelving, to control access and maximize protection } \\
\text { against record) }\end{array}$ \\
\hline b. & Furniture and floor carpet & $\begin{array}{l}\text { Furniture and floor carpets should not be made of materials that will attract } \\
\text { insects, preferably also non-combustible materials }\end{array}$ \\
\hline c. & Hallway & $\begin{array}{l}\text { The arrangement of storage locations and shelves should allow for } \\
\text { ventilation } \\
\text { Also consider wheelchair access, free trolley movement, stair access, and } \\
\text { other factors that require free aisle space. } \\
\text { Allocate sufficient area for the need for sorting records that have just been } \\
\text { received from the work unit or central file in anticipation that the hallway is } \\
\text { not filled with piles of boxes or boxes of records }\end{array}$ \\
\hline d. & Non-recorded items & $\begin{array}{l}\text { All types of waste or non-recorded objects must be immediately removed } \\
\text { from the record storage location without exception. }\end{array}$ \\
\hline e. & Wall and partitions between spaces & $\begin{array}{l}\text { Walls that have fire-resistant protection can be used as storage space and } \\
\text { records must be separated from the work area. } \\
\text { One of the efforts that can be done is to make partitions from large storage } \\
\text { spaces into smaller units by using fire-resistant separation walls as an effort } \\
\text { to increase fire protection, maintain temperature and humidity and increase } \\
\text { security. }\end{array}$ \\
\hline f. & Door & $\begin{array}{l}\text { Doors to storage areas must be locked, fireproof, wide enough to allow } \\
\text { movement of trolleys, and kept closed at all times. } \\
\text { If it is necessary to keep the door open during activities at the record center, } \\
\text { then the door must be equipped with a magnetic device designed to be able } \\
\text { to close automatically after the fire alarm or building security detection } \\
\text { system is activated. }\end{array}$ \\
\hline g. & Ceiling and floor & $\begin{array}{l}\text { The ceiling must be quite high, if possible with a distance of } 500 \mathrm{~mm} \\
\text { between the upper corner of the shelf and the fire sprinkler fire the goal is to } \\
\text { ensure that the sprinkler does not accidentally activate. } \\
\text { The thing that is also very important to be calculated is the maximum } \\
\text { ability of the floor holding the load when the shelving shelves are full of } \\
\text { racks (highly recommended that the architect and civil engineering section } \\
\text { count and provide recommendations on floor structures and density so that } \\
\text { it can be a consideration when will procure shelves or mobile Shelving) } \\
\text { Materials used for walls, ceilings, and doors must be from hard material and } \\
\text { will not cause dust or sand } \\
\text { The internal structure in the storage space must be in good condition and } \\
\text { not remove acid gas, which when decomposes will be a fire target }\end{array}$ \\
\hline h. & Window & $\begin{array}{l}\text { Buildings or rooms used for record storage should not have windows and, if } \\
\text { any, windows facing west should be avoided as they endanger records from } \\
\text { light and heat. } \\
\text { If windows persist, the steps to take to prevent light and heat from entering } \\
\text { are: } \\
\text { Installing curtains on windows or blinds, it is recommended to use heat- } \\
\text { absorbing cloth, to reduce or eliminate lighting } \\
\text { Install window film to prevent the entry of ultraviolet rays }\end{array}$ \\
\hline
\end{tabular}

\section{CONCLUSION}

Theoretically, the results of this research are expected to provide understanding and knowledge about the needs of an archive center (record center) following the ideal form, standards, and various laws and regulations regarding the management of university archives for stakeholders, especially those in FISIP UNILA and the general public in Lampung University. This research is also expected to increase the scope of studies in the archives field at the
University of Lampung, especially in the D3 Study Program of the Unila Fisip Library, which is also preparing to upgrade from the D3 level to the S1 Study Program of Applied Archives and Documentation.

Practically, the data findings from this research are expected to be a guide for developing an archive center or record center at the Faculty of Social and Political Sciences, University of Lampung. At the same time, it is hoped that it can be a reference for 
other faculties and work units within the scope of the University of Lampung who will develop their archive center in the future. Following applicable standards and laws and regulations. Furthermore, it is hoped that this will be obtained as preliminary data for future archival studies.

The findings targeted in this study include a model and practical guidelines in the development of an archive warehouse into a record center at FISIP UNILA and data and information on the existing condition of record management or archives at FISIP UNILA.

\section{ACKNOWLEDGMENT}

The researcher would like to thank the LPPM, University of Lampung, for funding this research through the 2021 Unila DIPA scheme. The researcher also thanked the Unila FISIP dean for providing great support so that this research can be completed and hopefully it will be useful for all of us.

\section{REFERENCES}

[1] Airlangga, S. P., Faisal, T., \& Nugraha, M. C. R, 'Archival Management at the University of Lampung,' FIAT JUSTISIA:Jurnal Ilmu Hukum, 12(4), 2018.https://doi.org/10.25041/fiatjustisia. v12no4.1371

[2] Amsyah, Z, 'Manajemen Kearsipan,' Gramedia Pustaka Utama, 2003.

[3] Caplan, P. 'Building a digital preservation archive: Tales from the front,' VINE, 34(1), 38-42, 2004, https://doi.org/10.1108/0305572 0410530988

[4] Cheney, D, 'A strategic plan for managing and preserving electronic records in New York state government: Final report of the special media records project,' Government Information Quarterly, 8(3), 1991, pp. 332. https://doi.org/10.1016/0740-624X(91)90075-J

[5] Esteva, M, 'Formation process and preservation of a natural electronic archive,' Proceedings of the American Society for Information Science and Technology, 45(1), 2009, pp. 1-9. https://doi.org/10.1002/meet.2008.1450450270

[6] Fahmi Abidin. 'Erick Thohir Batalkan Pembangunan Gedung Arsip BUMN Senilai Rp50 Miliar,' 2019. https://www.idxchannel.com/. https://www.idxchannel.com/market-news/erick-thohirbatalkan-pembangunan-gedung-arsip-bumn-senilai-rp50 miliar

[7] Grau, O. (Ed.), 'Digital Art's Complex Expression and Its Impact on Archives and Humanities: For a Concerted Museum-Network of Expertise and Preservation,' Dalam W.
Coones \& V. Rühse, Museum and Archive on the Move, 2017, pp. 99-117. De Gruyter. https://doi.org/10.1515/9783110529630-007

[8] Hirschler, 'From Archive to Archival Practices: Rethinking the Preservation of Mamluk Administrative Documents,' Journal of the American Oriental Society, 136(1), 2016, pp.1. https://doi.org/10.7817/jameroriesoci.136.1.1

[9] ICA-International Council on Archives, 'What are Archives? International Council on Archives, 2016, https://www.ica.org/en/ what-archive.

[10] Indah Aprilin Cahyani, 'Batalkan Rencana Pembangunan Gedung Arsip BUMN, Erick Thohir: Saya Rasa Sekarang Eranya Sudah iCloud,' 2019, https://www.tribunnews.com. https://www.tribunnews. com/nasional/2019/12/15/batalkan-rencana-pembangunangedung-arsip-bumn-erick-thohir-saya-rasa-sekarang-eranyasudah-icloud.

[11] Indonesia. Kemendikbud, 'Undang-Undang Nomor 12 Tahun 2012 Tentang Pendidikan Tinggi,' Kemendikbud, 2012.

[12] Miles, M. B, 'Analisis Data Kualitatif (Terjemahan),' UI Press. 1992

[13] Paul H. MC Carthy, 'The Management of Archives: A Research Agenda. American Archivist, 51(Winter and Spring 1988,' 1988, pp. 52-70.

[14] Pouchard, L., 'Revisiting the Data Lifecycle with Big Data Curation,' International Journal of Digital Curation, 10(2), 2016, pp. 176-192. https://doi.org/10.2218/ijdc.v10i2.342

[15] Prodi D3 Pepustakaan, 'Tentang Prodi D3 Perpustakaan FISIP Universitas Lampung,' Prodi D3 Perpustakaan FISIP Unila, 2021. https://perpustakaan.fisip.unila.ac.id/

[16] Randall C. Jimerson 'Archives for All: Professional Responsibility and Social Justice. The American Archivist,' Society of American Archivists, 70(2), 2007, pp. 252-281.

[17] Richard Pearce-Moses, 'A Glossary of Archival and Records Terminology (Laurie Baty, Ed.),' The Society of American Archivists, 2005. https://files.archivists.org/pubs/free/SAAGlossary-2005.pdf

[18] Silver, B. C, 'Guidelines for arrangement and description of archives and manuscripts: A manual for historical records programs in New York State,' Government Publications Review, 20(4), 1993, pp. 473-474. https://doi.org/10.1016/0277-9390(93)90049-U

[19] Sulistyo-Basuki, 'Manajemen Arsip Dinamis,' Gramedia Pustaka Utama, 2003.

[20] Undang-Undang Republik Indonesia Nomor 43 Tahun 2009 tentang Kearsipan, Nomor 43 Tahun 20098 (2009).

[21] Vaismoradi, M., Turunen, H., \& Bondas, T, 'Content analysis and thematic analysis: Implications for conducting a qualitative descriptive study: Qualitative descriptive study,'Nursing \& Health Sciences, 15(3), 2013, pp. 398-405. https://doi.org/10.1111/nhs.12048 